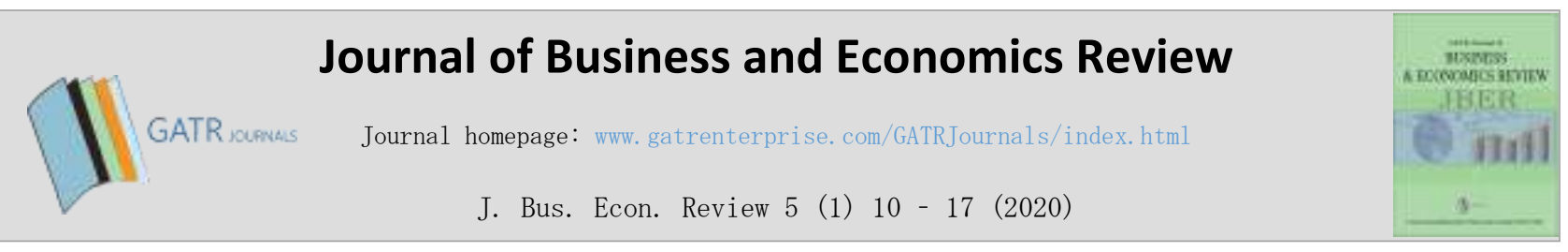

\title{
Mungbean (Vigna radiata) as a Source of Income among Farmers
}

\author{
Mar Heisen A. Yanos $^{1 *}$, Rosalie C. Leal ${ }^{2}$ \\ ${ }^{1}$ Isabela State University, San Mateo, Isabela,3318, Philippines \\ ${ }^{2}$ Isabela State University, San Mateo, Isabela,3318, Philippines
}

\begin{abstract}
Objective - This study assesses the impact of mungbean (Vigna radiata) as a source of income among San Mateo folks. More specifically, this study aims to measure the benefits of respondents derived from mungbean as a source or additional income and the creation of a database of the generated activities, employment and innovative projects from mungbean.

Methodology/Technique - The respondents of the study were 100 mungbean growers that were randomly selected within San Mateo. Data was collected using a structured questionnaire and focus group discussion and was analyzed using frequency and percentage.

Findings - The data analysis reveals that mungbean farming generates both income and employment. The findings also reveal that a return of investment of $132.66 \%$ per hectare can be generated in producing mungbean.

Novelty -This study aims to validate the economic impact of mungbean production among the people in San Mateo, Isabela. It is also the goal of this study to analyze how the production of mungbean helps increase employment in the community.
\end{abstract}

Type of Paper: Empirical.

Keywords: Mungbean; Assessment; San Mateo; Productivity; Farmers.

Reference to this paper should be made as follows: Yanos, M. H. A.; Leal, R. C., (2020). Mungbean (Vigna radiata) as a Source of Income among Farmers, J. Bus. Econ. Review, 5(1) 10 - 17, https://doi.org/10.35609/jber.2020.5.1(2)

JEL Classification: Q12, Q14.

\section{Introduction}

While the world is constantly changing and growing, the needs of humans also change. This means that the standard of living should also improve, which could be difficult for an ordinary farmer to attain, knowing that farming is not always about profit or fortune due to unexpected circumstances that destroy crops such as natural calamities. Many farmers earn an average of Php. 12 per kilo for palay. People from other areas in the rice-growing parts of the country experience some greedy wholesalers with a farm-gate at Php 8 per kilo only in the Philippines which is severely detrimental to their source of income. Mungbean is a short maturing crop which plays an important role in crop diversification as a cash crop, intercrop, and as a rotation crop of rice and corn.

\footnotetext{
* Paper Info: Revised: January 12, 2020

Accepted: March 30, 2020

* Corresponding author: Mar Heisen A. Yanos

E-mail: 317mar@gmail.com

Affiliation: Isabela State University, San Mateo, Isabela,3318, Philippines
} 
Mungbean, a small green legume grown widely for food consumption and a popular alternative to meat and vegetables, is one of the cheapest sources of protein in the Filipino diet. It is also high in potassium, fibre, magnesium, and B vitamins. Other than its guaranteed nutrients, mungbean is also a soil fertility crop ( $\mathrm{N}$-fixing and source of green manure), and, unlike other crops, it is a drought-tolerant or climate-change resilient crop.

For these reasons, the Industry Strategic Program of the DOST-PCAARRD regards mungbean as one of the priority commodities, highlighting its' economic importance. Reader's Digest (2012) considered it as a "wonder crop" and one of the five foods that could save the world.

As a result, this study would like to validate the economic impact of mungbean production among the farmers in San Mateo, Isabela. It is also the goal of this study to analyze how the production of mungbean helps increase employment in the community. Ultimately, it could serve as a basis in the formulation of innovative projects with mungbean as the primary element. A focus group discussion was used to gather the data for this study.

\section{Literature Review}

\subsection{Importance of Mungbean as an Agricultural Crop}

Mungbean can be used as a green manure crop and for forage for livestock (Oplimger et. al., 1990) With the development of short duration and uniform maturing varieties, mungbean can be utilized for various cropping systems and can also be used as a cash crop between major cropping seasons. It can improve soil nutrients, reduce chemical use in the rotation due to improved pest control, and reduce the use of nitrogen fertilizer in a rotation. If the new varieties lead to increases in the annual amounts of mungbeans planted, then such additional benefits can be attributed to the new varieties (GRDC, 2011; Pataczek, 2018).

Moreover, mungbean can be used as a cover crop before or after cereal crops because it has a $\mathrm{N}$-fixing bacteria that can provide large amounts of biomass (7.1 biomass/ha) and $\mathrm{N}$ to the soil (ranging from 30 to 251 kg/ha) (Hoorman et. al., 2009; George et. al., 1995 cited by Devendra et. al., 2001; Meelu et. al., 1992). The integration of N-fixing pulses with short growth cycles into the cropping calendar is a useful coping strategy, allowing for crop diversification under limited rainfall. According to Singh et. al., a lack of cropsaving, supplementary irrigation at critically low soil moisture levels hampers plant growth and crop productivity (Pataczek, et. al., 2018).

As to human consumption, mungbean has a potential contribution to food security (Patazeck et. al., 2018). Exploring the potential of mungbean to fight hidden hunger by linking it to national food policies would also help to boost farming income, but would also require shifts in available on-farm technology to improve gender equality, as currently harvest is typically conducted manually and can be looked at as another crop to diversify the crop based on a farm (Pataczek et. al., 2018; Delate, 2018)

\subsection{Economic Importance of Mungbean}

Currently, the world production area of mungbean is about six-million hectares per year, out of which $90 \%$ is grown in Asia with an average yield of $400 \mathrm{~kg} / \mathrm{ha}$. The productivity of mungbean is still low, but the demand might increase in the future due to its high dietary quality. Mungbean production cannot only increase a farmer's income through the sale of beans, but also through the reduction of farm inputs after cultivation (Pataczek et. al., 2018)

Mungbean can be easily cultivated. In 2006, mungbean contributed approximately 790 million pesos (or $\$ 39.2 \mathrm{M}$ ) to the Philippine economy (PCARRD-DOST, 2003). Growing this crop after rice also offers farmers a good opportunity to earn additional income since it only requires minimum input for production 
(Lagasca, 2008), while offering a variety of applications including sotanghon and hopia manufacturing, cereal flour and noodle production, bread and snack making, and the like (Balinao et. al., 2019). In fact, the mungbean is now so popular that it is selling at four times the price of sorghum, which means more money for farming families that desperately need it (Hetrick, 2016).

\section{Research Methodology}

Mungbean farmers were randomly selected from the different barangays involved in mungbean production. Data was collected using a structured questionnaire, which was designed for this study, and through Focus Group Discussions (FGD). Group participants were informed about the purpose of the study. Participants were asked to interact freely with each other. The collected data was computed using frequency and percentage and then analyzed to fulfil the objectives of the study. The profitability of mungbean production was examined based on the return on investment.

\section{Results and Discussion}

Table 1. Socio-demographic profile of respondents

\begin{tabular}{|c|c|c|c|}
\hline \multicolumn{2}{|c|}{ Socio-economic Variable } & \multirow[t]{2}{*}{ Frequency } & \multirow[t]{2}{*}{ Percentage } \\
\hline Sex & & & \\
\hline & Male & 73 & $73 \%$ \\
\hline & Female & 27 & $27 \%$ \\
\hline \multicolumn{4}{|l|}{ Age } \\
\hline & Below 30 & 27 & $27 \%$ \\
\hline & $30-39$ & 11 & $11 \%$ \\
\hline & $40-49$ & 38 & $38 \%$ \\
\hline & $50-59$ & 19 & $19 \%$ \\
\hline & Above 60 & 5 & $5 \%$ \\
\hline \multicolumn{4}{|c|}{ Marital Status } \\
\hline & Single & 20 & $20 \%$ \\
\hline & Married & 75 & $75 \%$ \\
\hline & Divorced & 4 & $4 \%$ \\
\hline & Widow & 1 & $1 \%$ \\
\hline \multicolumn{4}{|c|}{ Household Size } \\
\hline & Less than 4 & 36 & $36 \%$ \\
\hline & $5-9$ & 49 & $49 \%$ \\
\hline & $10-15$ & 5 & $5 \%$ \\
\hline & More than 15 & 0 & $0 \%$ \\
\hline \multicolumn{4}{|c|}{ Production of Mungbean Farming Experience } \\
\hline & $0-5$ Years & 23 & $23 \%$ \\
\hline & 6-10 Years & 22 & $22 \%$ \\
\hline & 11-15 Years & 17 & $17 \%$ \\
\hline & Above 15 Years & 38 & $38 \%$ \\
\hline \multicolumn{4}{|c|}{ Level of Education } \\
\hline & No Education & 12 & $12 \%$ \\
\hline & Primary Education & 20 & $20 \%$ \\
\hline & Secondary Education & 44 & $44 \%$ \\
\hline & Tertiary Education & 24 & $24 \%$ \\
\hline
\end{tabular}


The data reveals that most of the respondents are male (73\%) falling within the ages of 40-49 (38\% of the total number of the respondents). Further, $75 \%$ of the respondents are married and most of them are secondary graduates (44\%). In addition, most of the respondents have a household size of 5-9 or $49 \%$, less than 4 household size is $36 \%$, and $15 \%$ with a household size of 10-15. Most of the respondents (38\%) have more than 15 years' experience in mungbean farming, followed by $0-5$ years $(23 \%), 6-10$ years $(22 \%)$, and $11-15$ years $(17 \%)$.

Table 2. No. of harvesters per hectare

\begin{tabular}{|c|c|c|}
\hline No. of Laborers & Frequency & Percentage \\
\hline Less than 10 & 26 & $26 \%$ \\
\hline 10 to 15 & 36 & $28 \%$ \\
\hline 16 to 20 & 28 & $10 \%$ \\
\hline 21 and above & 10 & $36 \%$ \\
\hline
\end{tabular}

Table 2 shows the number of mungbean farmers during harvest season. During this season, 10-15 farm laborers work per hectare, which means that there is a significant impact of munggo production in the employment generation.

Table 3. Marketing

\begin{tabular}{|c|c|c|}
\hline Marketing Activities & Frequency & Percentage \\
\hline All are sold to market & 35 & $35 \%$ \\
\hline All are stocked for family consumption & 1 & $8 \%$ \\
\hline All are stocked for the next cropping & 8 & $48 \%$ \\
\hline Both sold to market and for family consumption & 48 & $8 \%$ \\
\hline Both sold to market and stocked for the next cropping & 8 & $1 \%$ \\
\hline
\end{tabular}

Table 3 shows the different practices done by the famers after threshing their mungbean. This means that most (48\%) of the respondents choose to sell and consume the largest portion of their mungbean produce, while other farmers $(35 \%)$ choose to sell all their mungbean, and some $(8 \%)$ choose to sell and stock their mungbean for the next cropping season. This implies that successful mungbean growers need to understand the mungbean consumers' fundamental requirements as stated in the mungbean management guide (2010). This result is supported by the study of Hothongcum (2014) and Gaffney (2013) who report that different attitudes among farmers and decision-making are largely driven by prices and costs.

Table 4. Mungbean Production data 


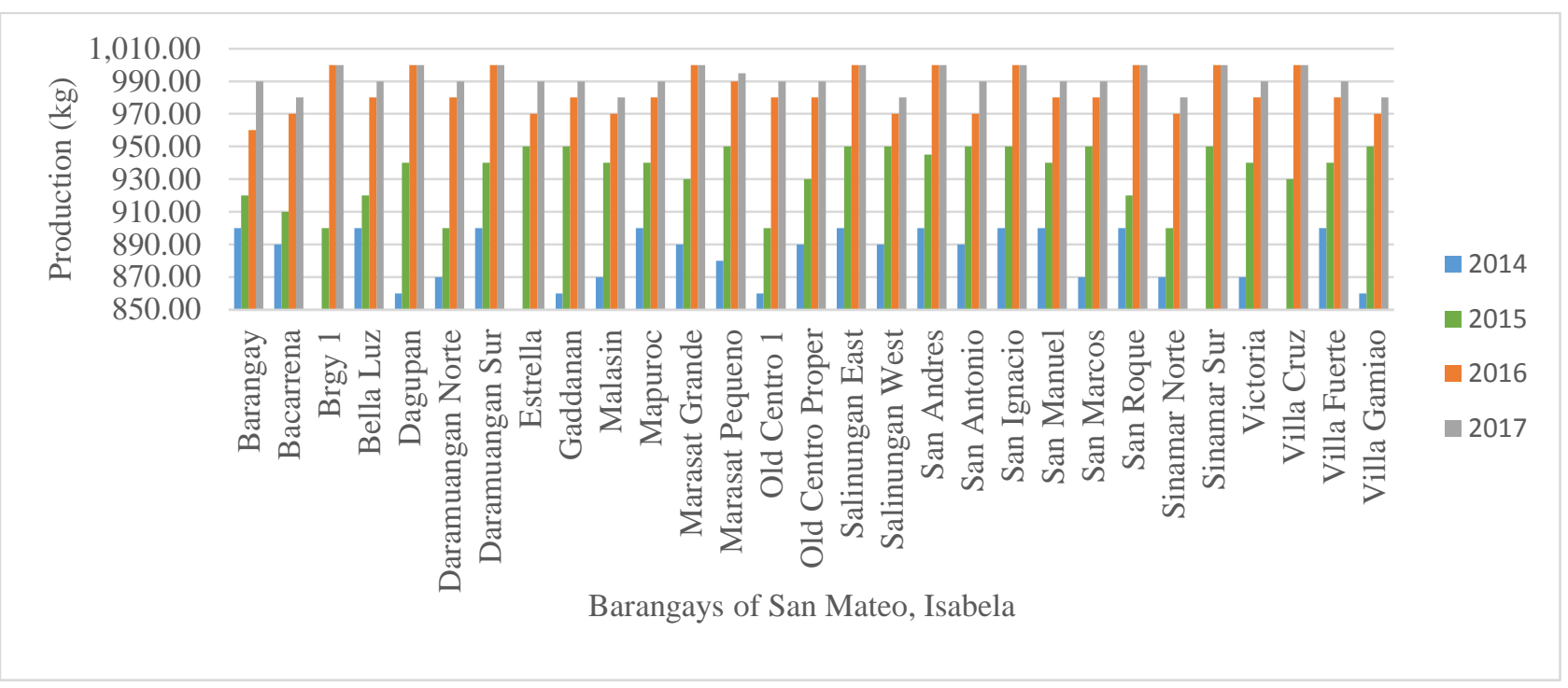

Table 4 shows the production of mungbean from the different barangays of San Mateo from 2014 to 2017, which shows an increase in production for the past 4 years. According to Benge (2017), when production levels increase, this means that more profits can be generated and there is a lower unemployment during the harvest season.

Table 5. Cost and Return Analysis for Mungbean and Rice per Hectare at San Mateo, Isabela

5.a Mungbean

\begin{tabular}{|c|c|c|c|c|}
\hline \multicolumn{2}{|c|}{ Production Cost } & Cost/ Unit (Php) & Quantity & Amount (Php) \\
\hline & a. Material Cost & & & 20 kgs. \\
\hline Seeds & 100.00 & 6 packs & 90.00 \\
\hline & Inoculants & 15.00 & 2 packs & 500.00 \\
\hline & Crop giant & 250.00 & 1 bundle & 50.00 \\
\hline & Twine & 50.00 & 22 pcs. & 330.00 \\
\hline & Sacks & 15.00 & 5 litres & 270.00 \\
\hline & Guddling of Rice stubbles and Flushing & 54.00 & $1 / 2$ MMD & 200 \\
\hline & Irrigation & 400.00 & & 400.00 \\
\hline & Inoculation of Seeds and Planting & 200.00 & 2 MMD & 800.00 \\
\hline & Spraying & 200.00 & 4 MMD & $1,000.00$ \\
\hline & Total Cost of Production & 200.00 & 5 MMD & $9,000.00$ \\
\hline
\end{tabular}

J. Bus. Econ. Review 5 (1) 10 - 17 (2020) 
Total Cost of Production

Gross Income

Net Income

Return of Investment
Php. 23,640.00

Php. 49,500.00

Php. 31.360.00

$132.66 \%$

5. b. Rice

\begin{tabular}{|c|c|c|c|}
\hline Items & Cost/ Unit (Php) & Quantity & Amount (Php) \\
\hline \multicolumn{4}{|l|}{ a. Supplies and Materials } \\
\hline Seeds & 1200 & 1.5 cavan & 1800 \\
\hline Insecticide & & & 1400.00 \\
\hline Herbicide & & & 700.00 \\
\hline Fertilizer & 1200 & 10 cavans & 12000.00 \\
\hline Foliar Fertilizer & 500.00 & $1 \mathrm{~kg}$ & 500.00 \\
\hline \multicolumn{4}{|l|}{ b. Labor Cost } \\
\hline Land Preparation & 5000 & 1 hectare & 5000.00 \\
\hline Uprooting & & & 2200.00 \\
\hline Planting & 5000 & 1 hectare & 5000.00 \\
\hline Harvesting & \multicolumn{2}{|c|}{$10 \mathrm{cav} / 100 \mathrm{cav}$} & 6550.00 \\
\hline Farm Laborer & \multicolumn{2}{|c|}{$2 \mathrm{cav} / 100 \mathrm{cav}$} & 6550.00 \\
\hline Drying & & & 500 \\
\hline Total Cost of Production & & & $42,200.00$ \\
\hline
\end{tabular}

Total Cost of Production

Gross Income

Net Income

Return of Investment
Php. 42,200.00

Php. 65,500.00

Php. 23,300.00

$55.21 \%$

Mungbean farmers incurred a total production cost of Php 23,640. The total gross income per hectare is Php. 49,500. This implies that there is $132.66 \%$ return of investment in producing mungbean per hectare. For rice production, farmers can generate a net income of Php 23,300, equal to a return of investment of 55.21\%. The whole duration of mungbean season lasts for 65-70 days, while rice lasts for 120 days. This indicates that mungbean production generates a higher profit for the farmers.

The increase in profit assists in analysing the ability of the farmers to capture opportunities, to maintain or increase production, and to attract higher prices with lower costs of production. It is supported by the statement of Ordoñez (2017) who says that using a return of investment (ROI) approach in agriculture would accelerate agricultural development. 


\subsection{Findings from Focus Group Discussions (FGD)}

Based on the FGD conducted, mungbean provides an additional source of income to the farmers, different organizations and individuals by selling processed mungbean products like butchi, munggo polvoron, pancit balatong, chips, coffee, and flour, which are already available in the market. Other farmers produce other processed products for local consumption. This finding is supported by the study of Dahiya et. al., (2015).

In the case of Ms. Cadeliña, one of the munggo entrepreneurs, she swears that her life has changed due to the munggo butchi she is selling. With 200 pieces of butchi at Php 2.00 per piece, she can easily earn a net income of P300 a day. "I started doing this when my daughter was on her first year. I've solely depended on butchi," says Ms. Cadeliña in Ilocano. Her husband earns too little from driving a tricycle.

There are many more like them. Some of them are strong-fisted, independent women who make a living out of munggo to get their family through the planting seasons. These women have tried all sorts of munggo products from moriecos to kropek, polvoron, hopia, pancit balatong, munggo flour, munggo coffee and others. It is supported by the study of Doss (2002) who said that mungbean is recognized as women's crops in many smallholder farming communities.

It is also worth mentioning that even children earn from picking mungbean pods. Children are able to save for their school supplies come June. It also provides equal opportunity for all those who want to harvest. It does not need any requirements for them to be accepted and does not need judgment and skill. Regardless of the level of education, everyone can be accepted. The cash flow they generate is marginal, but plays a significant role in meeting household needs and improving health and education (Kalansooriya et. al., 2014).

\section{Conclusion}

Based on the findings of this study, it can be concluded that mungbean production has several impacts particularly on the farmers of San Mateo, Isabela. Due to the low input required compared to other crop productions, mungbean recorded an increase of income at Php 31, 360.00 per hectare during summer season. This means that a single farmer who has more than one hectare could earn twice or three times the increase of income recorded. Moreover, mungbean production could generate employment for between 10-15 persons per hectare. Thus, larger land area could provide a higher rate of employment opportunities to more people in the community regardless of their sex, age and educational level.

Although mungbean is seasonal, its flexibility is also worthy to note. Mungbean farmers of San Mateo, Isabela have attested that there are a number of products that can be made out of mungbean. Its flexibility could help any person innovate mungbean products that are in the first place already available in the market. With this, households can provide their own supply, though limited, without having to rely on market supplies. This implies then that every family is guaranteed with nutrients out of mungbean, way more affordable than other goods that do not guarantee health benefits. But in order to realize this, there is a need to educate every mungbean farmer, or any interested person, who wants to gain additional income out of mungbean.

Of all these, people in the community could attain a more sustainable way of living out of mungbean crop and products. This could help them cope with the increasing demands of our world, thereby, perhaps, reducing the number of those who live within the poverty index.

\section{References}

Balinado, L., Manzano, R. M. E., Ate, C. M., Fernandez, M., \& Chan, M. A. (2019). Early vegetative growth responses of Vigna radiata L. (Mungbean) cv NSIC Mg 17 to boron toxicity. Journal of Nature Studies, 18(1), 1121.https://www.researchgate.net/publication/332103653_Early_Vegetative_Growth_Responses_of_Vigna_radiata_L_ Mungbean_cv_NSIC_Mg_17_to_Boron_Toxicity 
Dahiya, P.K., Linnemann, A.R., Van Boekel, M.A.J.S. et. al (2015). Mungbean: technological and nutritional potential. Critical Reviews in Food Science and Nutrition, 55:5, 670-688, DOI:10.1080/10408398.2012.671202

Dorward, A. (2013). Agricultural labour productivity, food prices and sustainable development impacts and indicators. Food Policy, 39, 40-50. https://doi.org/10.1016/j.foodpol.2012.12.003

Doss, C. R. (2002). Men's crops? Women's crops? The gender patterns of cropping in Ghana. World Development, 30(11), 1987-2000. https://doi.org/10.1016/S0305-750X(02)00109-2

Fischer, T. B., \& Noble, B. (2015). Impact assessment research: achievements, gaps and future directions: introduction to the March 2015 special issue of the Journal of Environmental Assessment Policy and Management. https://doi.org/10.1142/S1464333215010012

Gaffney, A., Slakie, E., Anderson, C. L., \& Gugerty, M. K. (2019). Why Attitudes Matter: Measuring Farmer Attitudes in Agricultural Development. Gates Open Res, 3. (https://doi.org/10.21955/gatesopenres.1115397.1)

Haugen,M.S. and Brandth, B. (1994). Gender differences in modern agriculture: gender \& society, 8(2), 206-229. DOI: $10.1177 / 089124394008002005$

Hetrick, H. (2016). Mungbean-transforming appetites and agriculture. https://www.concernusa.org/story/themysterious-mung-bean-transforming-appetites-and-agriculture/

Hothongcum, K., Suwunnamek, O., \& Suwanmaneepong, S. (2014). Assessment of Farmers Knowledge and Attitude Towards the Commercialitation of Tailor-made Fertilizers in Thailand. Asian Journal of Scientific Research, 7(3), 354365. 10.3923/ajsr.2014.354.365

Islam, Q. S., Rahman, M. S., Hossain, M. A., \& Hossain, M. S. (2011). Economic analysis of mungbean (vigna radiata) cultivation in some coastal areas of Bangladesh. Bangladesh Journal of Agricultural Research, 36(1), 29-40. https://doi.org/10.3329/bjar.v36i1.9227

Kalansooriya, C.W. and Chandrakumara, D.P.S. (2014) Women's role in household food security in rural Sri Lanka. International Journal of Multidisciplinary Studies. Volume I, Issue I, 2014. https://doi.org/10.31357/ijms.vlil.2238

Kedir, A. (2005). Socioeconomic impact of export oriented agricultural production on farmers, in eastern Ethiopia.https://pdfs.semanticscholar.org/da47/2f58a1c373abaddf3a3f810594ccd7aac15c.pdf

Lovell, Ca \& Grifell - Tatjé, Emili. (1996). Profits and Productivity by. Management Science. 45. 10.1287/mnsc.45.9.1177.

Machethe, C. (2004) Agriculture and poverty in south Africa: can agriculture reduce poverty? Paper presented at the Overcoming Underdevelopment Conference. https://pdfs.semanticscholar.org/5819/9fe4929521b6df750f02b5182e7040a73c40.pdf

Mogues, T., Yu, B., Fan, S., \& McBride, L. (2012). The impacts of public investment in and for agriculture. Synthesis of the Existent Evidence.http://www.fao.org/3/a-ap108e.pdf

Nouman, M., Siddiqi, M., Asim, S., \& Hussain, Z. (2013). Impact of socio-economic characteristics of farmers on access to agricultural credit. Sarhad Journal of Agriculture, 29(3), 469-476. https://ssrn.com/abstract=2336223

Pataczek, L., Zahir, Z. A., Ahmad, M., Rani, S., Nair, R., Schafleitner, R., ... \& Hilger, T. (2018). Beans with Benefits-The Role of Mungbean (Vigna radiate) in a Changing Environment. American Journal of Plant Sciences, 9(07), 1577.https://doi.org/10.4236/ajps.2018.97115

Dahiya, P. K., Linnemann, A. R., Nout, M. J., Van Boekel, M. A., Khetarpaul, N. K., \& Grewal, R. B. (2014). Consumption habits and innovation potential of mung bean foods in Hisar District of Haryana State, India. Ecology of food and nutrition, 53(2), 171-192. DOI: 10.1080/03670244.2013.807809

Islam, Q. S., Rahman, M. S., Hossain, M. A., \& Hossain, M. S. (2011). Economic analysis of mungbean (vigna radiata) cultivation in some coastal areas of Bangladesh. Bangladesh Journal of Agricultural Research, 36(1), 29-40. http://dx.doi.org/10.3329/bjar.v36i1.9227 